\title{
ASUPAN GIZI DAN POLA MAKAN IBU MENYUSUI ASI EKSKLUSIF DI WILAYAH KERJA UPT PUSKESMAS IBRAHIM AJI KOTA BANDUNG
}

\author{
Nutrition Intake and Dietary Pattern of Exclusive Breastfeeding Mother in The Working Area of UPT \\ Puskesmas Ibrahim Aji Bandung City
}

\author{
Yusrima Syamsina Wardani ${ }^{1}$, Ginna Megawati ${ }^{2}$, Dewi Marhaeni Diah Herawati ${ }^{3}$ \\ ${ }^{1}$ Program Studi Magister IImu Kesehatan Masyarakat Fakultas Kedokteran Universitas Padjadjaran \\ ${ }^{1}$ Program Studi D4 Kebidanan Fakultas Kedokteran Universitas Padjadjaran \\ 2,3Divisi IImu Gizi Medik Departemen IImu Kesehatan Masyarakat \\ Fakultas Kedokteran Universitas Padjadjaran \\ E-mail: yusrima25@gmail.com
}

\begin{abstract}
Breast milk is the best food for babies for growth and development. The purpose of this study was to determine the nutritional intake and diet of mothers who provide exclusive breastfeeding. This research design was a mixed method with a sequential explanatory strategy. Quantitative research to assess food intake, while qualitative research was used to determine the dietary patterns of mothers. Quantitative samples were 44 mothers, while qualitative samples were 5 mothers, conducted by purposive sampling. Quantitative data collection by multiple 24-hour recalls for 3 days. Qualitative data collection by in-depth interviews. Quantitative analysis was conducted descriptively, while qualitative data were analyzed using content analysis. The results showed that intake of energy $(36.63 \%)$ and protein $(40.90 \%)$ of inadequate breastfeeding mothers (adequate if $\geq 80 \%$ ). For vitamin $A$, vitamin $B 1$, vitamin $B 2$, vitamin $B 6$, vitamin $C$, iron, and zinc the intake is below the RDA. Mothers who provide exclusive breastfeeding have a diet such as types of food that are not diverse, amount of food that is not certain, frequency and schedule of irregular meals. The nutritional intake and diet of breastfeeding mothers are not by guidelines for balanced nutrition.
\end{abstract}

Keywords: nutritional intake, dietary pattern, exclusive breastfeeding mothers

\section{ABSTRAK}

ASI adalah makanan terbaik bagi bayi untuk pertumbuhan dan perkembangan. Tujuan penelitian ini untuk mengetahui asupan gizi dan pola makan ibu yang memberikan ASI eksklusif di wilayah kerja UPT Puskesmas Ibrahim Aji Kota Bandung. Desain penelitian ini mixed method dengan strategi sequential explanatory. Penelitian kuantitatif untuk melihat asupan makan sedangkan penelitian kualitatif digunakan untuk mengetahui pola makan ibu yang memberikan ASI eksklusif. Jumlah sampel kuantitatif 44 orang, sedangkan kualitatif 5 orang, dilakukan secara purvosive sampling. Pengumpulan data kuantitatif dengan cara multiple 24 hour recall selama 3 hari. Pengumpulan data kualitatif dilakukan dengan wawancara mendalam. Analisis kuantitatif dilakukan secara deskriptif, sedangkan data kualitatif dengan content analysis melalui transkripsi, koding, kategorisasi, dan pembuatan tema. Hasil penelitian menunjukkan bahwa, asupan energi $(36,63 \%)$ dan protein $(40,90 \%)$ ibu menyusui tidak adekuat (adekuat jika $\geq 80 \%$ ). Untuk vitamin A, vitamin B1, vitamin B2, vitamin B6, vitamin C, kalsium, zat besi dan seng asupannya berada di bawah AKG. Ibu yang memberikan ASI eksklusif memiliki pola makan dengan jenis makanan yang tidak beragam, jumlah makanan yang tidak tentu, frekuensi dan jadwal makan yang tidak teratur. Asupan gizi dan pola makan belum sesuai dengan pedoman gizi seimbang.

Kata kunci: asupan gizi, pola makan, ibu menyusui ASI eksklusif 


\section{PENDAHULUAN}

$\mathrm{M}$ enurut United Nations International Children's Emergency Fund (UNICEF) tahun 2012 cakupan Air Susu Ibu (ASI) Eksklusif di dunia rata-rata sebesar 38 persen. ${ }^{1}$ Profil Kesehatan Indonesia tahun 2016 mengenai cakupan ASI eksklusif di Indonesia sebesar 29,5 persen dan di Jawa Barat sebesar 39,6 persen. ${ }^{2}$ Di Kota Bandung untuk cakupan ASI eksklusif tahun 2016 sudah melebihi angka cakupan nasional yaitu sebesar 56,06 persen, salah satu Puskesmas di Kota Bandung yang sudah melebihi cakupan nasional ASI eksklusif yaitu UPT Puskesmas Ibrahim Aji sebesar 78,12 persen.3,4

Kandungan ASI sangat kaya akan nutrisi dan menjadi kunci kesehatan bagi bayi. ${ }^{5}$ Air susu ibu adalah makanan terbaik yang dibutuhkan bayi usia 0-6 bulan untuk pertumbuhan dan perkembangan yang optimal, meningkatkan daya tahan tubuh, melindungi dari infeksi, membentuk sistem pencernaan yang sehat, dan meningkatkan kecerdasan. ${ }^{6,7}$ Pemberian ASI yang tidak eksklusif dapat meningkatkan mortalitas dan morbiditas pada bayi seperti infeksi saluran pernafasan (ISPA), demam, diare, peneumonia dan kekurangan gizi. $8,9,10$

Pada pemberian ASI eksklusif tidak semua bayi yang mendapatkan ASI dapat tumbuh dan berkembang dengan baik. Asupan ASI yang tidak adekuat menyebabkan bayi berisiko mengalami kekurangan gizi (gizi kurang, tubuh pendek dan kurus). Salah satu faktor yang berpengaruh terhadap kekurangan gizi pada bayi adalah kuantitas dan kualitas produksi ASI dari asupan gizi ibu yang kurang selama menyusui. ${ }^{11,9}$ Asupan gizi ibu selama menyusui mempengaruhi energi, komponen makronutrien dan mikronutrien dalam ASI. ${ }^{11}$ Pemenuhan menu gizi seimbang yang dianjurkan untuk ibu menyusui adalah protein, vitamin $A$, vitamin $B$, kalsium, zat besi, dan seng untuk memproduksi ASI, metabolisme tubuh ibu, dan berpengaruh terhadap komposisi ASI yang diberikan kepada bayinya. ${ }^{12,13}$ Penelitian terdahulu yang dilakukan di Shanghai dan Cina menyatakan bahwa kebiasaan diet ibu menyusui mempengaruhi makro dan mikronutrien dalam ASI. ${ }^{14,15}$ Penelitian di Cambridge menunjukkan bahwa ASI berpengaruh terhadap pertumbuhan bayi. ${ }^{16}$
Hasil penelitian di Pustu Desa Sepanjang Gondanglegi Kabupaten Malang, faktor yang mempengaruhi pola makan kurang baik yaitu dari interal (pengetahuan) dan faktor eksternal (pantangan makanan dan informasi nutrisi laktasi). ${ }^{17}$ Pada Penelitian di Desa Manisrejo Kec. Taman Kota Madiun menunjukan bahwa terdapat 78 persen ibu menyusui memiliki asupan nutrisi cukup dan 22 persen ibu menyusui memiliki asupan nutrisi kurang. ${ }^{18}$ Pada penelitian di Tlogo Indah Kecamatan Lowokwaru Malang menunjukan bahwa sebesar 40,6 persen memiliki pola makan yang normal pada ibu menyusui. ${ }^{19}$

Studi pendahuluan yang dilakukan peneliti pada bulan September 2018 di UPT Puskesmas Ibrahim Aji Kota Bandung menunjukan bahwa mayoritas ibu tidak paham mengenai gizi seimbang dan memiliki pola makan yang kurang baik. Padahal Puskesmas Ibrahim Aji merupakan salah satu Puskesmas dengan angka cakupan ASI eksklusif yang baik. Berdasarkan latar belakang tersebut, maka tujuan penelitian ini adalah untuk menganalisis asupan gizi dan menggali pola makan ibu yang memberikan ASI eksklusif di wilayah kerja UPT Puskesmas Ibrahim Aji Kota Bandung.

\section{METODE PENELITIAN}

Desain penelitian adalah mixed methode dengan strategi squential explanatory. Tahap pertama dilakukan penelitian kuantitatif untuk melihat asupan makan ibu yang memberikan ASI eksklusif. Tahap kedua dilakukan penelitian kualitatif untuk mendapatkan informasi yang mendalam mengenai pola makan ibu yang memberikan ASI eksklusif. Pada metode kualitatif, peneliti dapat mengembangkan pertanyaan-pertanyaan yang diajukan kepada subyek/ informan penelitian. Lokasi penelitian di wilayah kerja UPT Puskesmas Ibrahim Aji Kota Bandung. Penelitian ini dilakukan pada bulan Desember 2018 -Januari 2019.

Populasi terjangkau dalam penelitian kuantitatif adalah ibu yang memberikan ASI eksklusif di wilayah kerja UPT Puskesmas Ibrahim Aji. Kriteria inklusi pada penelitian ini yaitu, ibu yang memberikan ASI eksklusif, sehat dan bersedia menjadi sampel penelitian. Kriteria eksklusinya yaitu, tempat tinggal tidak menetap dan memiliki penyakit degeneratif dan infeksi. 
Besar sampel dihitung berdasarkan tujuan penelitian, untuk mengetahui asupan gizi dan pola makan ibu yang memberikan ASI eksklusif di wilayah kerja UPT Puskesmas Ibrahim Aji Kota Bandung. Perhitungan sampel menggunakan rumus besar sampel untuk penelitian analitik numerik tidak berpasangan (uji hipotesis dua rata-rata). ${ }^{20}$

Jumlah sampel minimal yang diperoleh adalah 20 dan untuk mengantisipasi adanya responden yang drop out, maka peneliti menambahkan sampel sebanyak 10 persen dari jumlah sampel awal, sehingga menjadi 22 orang. Kenyataan di lapangan terdapat jumlah sampel sebanyak 44 ibu yang memberikan ASI eksklusif.

Jadi, jumlah sampel pada penelitian kuantitatif sebanyak 44 ibu yang memberikan ASI eksklusif, dilakukan secara purposive sampling. Jenis data yang dikumpulkan dalam penelitian kuantitatif adalah data multiple 24 hour recall selama 3 hari untuk mengetahui gambaran kebiasaan makan pada 44 ibu yang memberikan ASI eksklusif. Berdasarkan AKG (Angka Kecukupan Gizi), kebutuhan energi (E), protein (P), vitamin $A($ vit.A), vitamin B1 (vit.B1), vitamin $B 2$ (vit.B2), vitamin B6 (vit.B6), vitamin $C$ (vit.C), kalsium (ca), zat besi (fe) dan seng (zn) adalah $E=2580 \mathrm{kkal} \& 2480 \mathrm{kkal}, \mathrm{P}=76 \mathrm{~g}$ \& $77 \mathrm{~g}$, vit. $A=850 \mathrm{mcg} \& 850 \mathrm{mcg}$, vit.B1 $=1,4$ $\mathrm{mg} \& 1,4 \mathrm{mg}$, vit.B2=1,8 $\mathrm{mg} \& 1,7 \mathrm{mg}$, vit.B6= $1,8 \mathrm{mg} \& 1,8 \mathrm{mg}$, vit.C= $100 \mathrm{mg} \& 100 \mathrm{mg}, \mathrm{ca}=$ $1300 \mathrm{mg} \& 1200 \mathrm{mg}, \mathrm{fe}=32 \mathrm{mg} \& 32 \mathrm{mg}, \mathrm{zn}=$ $15 \mathrm{mg} \& 15 \mathrm{mg}$. Hasil energi dan protein selama 3 hari dikategorikan adekuat (jika $\geq 80 \%$ AKG) dan tidak adekuat (jika $<80 \%$ AKG).

Penelitian kualitatif, untuk pemilihan informan dilakukan secara purposive sampling yang ditetapkan peneliti. Diperoleh 5 orang informan, berdasarkan kejenuhan data. Pengumpulan data kualitatif dilakukan dengan wawancara mendalam (in-depth interview). Wawancara mendalam dilakukan dengan menanyakan pola makan ibu menyusui. Pengambilan data kualitatif dan kuantitatif, dilakukan oleh peneliti tidak dibantu oleh enumerator. Peneliti telah mengikuti standarisasi baik dalam melakukan pengukuran asupan makan maupun pengambilan data kualitatif dari ahli dibidang tersebut.
Analisis data kuantitatif dilakukan berdasarkan pada skala pengukuran variabel dan diolah menjadi deskriptif. Data kategorik serta ukuran statistik yang disajikan dengan jumlah dan presentase. Data kualitatif didapatkan dari data wawancara 5 responden. Untuk memastikan kebenaran data kualitatif maka dilakukan triangulasi sumber yaitu dengan cara wawancara pada Bidan yang bertugas di UPT Puskesmas Ibrahim Aji. Hasil dari triangulasi sumber menyatakan bahwa pola makan ibu menyusui di wilayah kerja UPT Puskesmas ibrahim Aji kurang baik dalam konsumsi makanan, jumlah makanan yang dikonsumsi sedikit, frekuensi makan dan jadwal makan yang tidak tentu. Analisis data kualitatif dilakukan content analysis melalui transkripsi, koding, kategorisasi dan pembuatan tema.

Penelitian ini telah mendapatkan persetujuan etik dari Komisi Etik Penelitian Kesehatan dari Universitas Padjadjaran dengan nomer persetujuan etik: 1490/UN6.KEP/EC/2018.

\section{HASIL}

\section{Karakteristik Subyek Penelitian}

Jumlah subyek yang mengikuti penelitian ini adalah 44 orang ibu yang memberikan ASI eksklusif. Karakteristik subyek penelitian dapat dilihat pada Tabel 1. Pada Tabel 1, dapat dilihat bahwa 50 persen ibu yang memberikan ASI eksklusif berusia antara 20-30 tahun, berpendidikan SMA dan tidak bekerja. Sebagian besar ibu yang memberikan ASI eksklusif mempunyai anak lebih dari dua yaitu sebesar 86,36 persen.

\section{Asupan Gizi Subyek Penelitian}

Asupan gizi diperoleh dari hasil food recall 24 hours, selama 3 hari untuk mengetahui gambaran asupan makan pada 44 ibu yang memberikan ASI eksklusif. Tabel 2 menunjukan bahwa asupan energi dan protein pada ibu yang memberikan ASI eksklusif didalam kategori adekuat $(\geq 80 \% A K G)$, sedangkan vitamin $A$, vitamin $B 1$, vitamin $B 2$, vitamin $B 6$, Vitamin $C$, kalsium, zat besi dan seng pada ibu yang memberikan ASI eksklusif sebagian besar berada di bawah AKG. 
Tabel 1

Karakteristik Ibu yang Memberikan ASI Eksklusif

\begin{tabular}{ccc}
\hline Karakteristik Ibu Menyusui & Frekuensi $(\mathrm{n})$ & Persentase $(\%)$ \\
\hline Usia (tahun) & 2 & \\
$-\quad<20$ & 22 & 4,54 \\
$-\quad 20-30$ & 20 & 50,00 \\
$-\quad>30$ & & 45,45 \\
Pendidikan & 4 & 9,09 \\
$-\quad$ SD & 12 & 27,27 \\
$-\quad$ SMP & 22 & 50,00 \\
$-\quad$ SMA & 6 & 13,63 \\
$-\quad$ Perguruan Tinggi & 22 & 50,00 \\
Pekerjaan & 22 & 50,00 \\
$-\quad$ Bekerja & 44 & 100,00 \\
$-\quad$ Tidak Bekerja & 6 & 13,63 \\
$-\quad$ Total & 38 & 86,37 \\
Paritas & & \\
$-\quad 1$ & & \\
$-\quad 2$ & & \\
\hline
\end{tabular}

Tabel 2

Distribusi Asupan Energi, Protein, Vitamin A, Vitamin B1, Vitamin B2, Vitamin B6, Kalsium, Zat Besi dan Seng

\begin{tabular}{|c|c|c|}
\hline Asupan Gizi & $\mathrm{n}$ & Persentase (\%) \\
\hline \multicolumn{3}{|l|}{ Energi } \\
\hline - Adekuat ( $\geq 80 \%$ AKG) & 27 & 61,36 \\
\hline - Tidak adekuat ( $<80 \%$ AKG) & 17 & 38,63 \\
\hline \multicolumn{3}{|l|}{ Protein } \\
\hline - Adekuat ( $\geq 80 \%$ AKG) & 26 & 59,09 \\
\hline - Tidak adekuat ( $<80 \%$ AKG) & 18 & 40,90 \\
\hline \multicolumn{3}{|l|}{ Vitamin A } \\
\hline - Baik dari AKG & 16 & 36,36 \\
\hline - Kurang dari AKG & 28 & 63,63 \\
\hline \multicolumn{3}{|l|}{ Vitamin B1 } \\
\hline - Baik dari AKG & 3 & 6,81 \\
\hline - Kurang dari AKG & 41 & 93,18 \\
\hline \multicolumn{3}{|l|}{ Vitamin B2 } \\
\hline - Baik dari AKG & 5 & 5,00 \\
\hline - Kurang dari AKG & 39 & 88,63 \\
\hline \multicolumn{3}{|l|}{ Vitamin B6 } \\
\hline - Baik dari AKG & 3 & 6,81 \\
\hline - Kurang dari AKG & 41 & 93,18 \\
\hline \multicolumn{3}{|l|}{ Vitamin C } \\
\hline - Baik dari AKG & 6 & 13,63 \\
\hline - Kurang dari AKG & 38 & 86,36 \\
\hline \multicolumn{3}{|l|}{ Kalsium } \\
\hline - Baik dari AKG & 5 & 11,36 \\
\hline - Kurang dari AKG & 39 & 88,63 \\
\hline \multicolumn{3}{|l|}{ Zat Besi } \\
\hline - Baik dari AKG & 5 & 11,36 \\
\hline - Kurang dari AKG & 39 & 88,63 \\
\hline \multicolumn{3}{|l|}{ Seng } \\
\hline - Baik dari AKG & 1 & 2,27 \\
\hline - Kurang dari AKG & 43 & 97,72 \\
\hline
\end{tabular}


Tabel 3

Distribusi Asupan Makan Ibu yang Memberikan ASI Eksklusif Perhari dari Data Recall

\begin{tabular}{lcc}
\hline Konsumsi Makanan & $\begin{array}{c}\text { Frekuensi makan perhari } \\
\geq 3 \text { kali }(\%)\end{array}$ & $\begin{array}{c}\text { Frekuensi makan perhari } \\
<3 \text { kali }(\%)\end{array}$ \\
\hline Makanan pokok per hari & 61,36 & 38,63 \\
Konsumsi sumber protein & 59,09 & 40,90 \\
Sayur & 27,27 & 72,72 \\
Buah & 20,46 & 79,54 \\
Kue - kue & 70,46 & 29,54 \\
Teh manis & 70,46 & 29,54 \\
\hline
\end{tabular}

Tabel 4

Karaktersitik Informan Wawancara Pola Makan

\begin{tabular}{lcc}
\hline Nama & Kode & Pekerjaan \\
\hline Responden 1 & R1A & IRT \\
Responden 2 & R2A & IRT \\
Responden 3 & R3A & IRT \\
Responden 4 & R4A & IRT \\
Responden 5 & R5A & IRT \\
\hline
\end{tabular}

Tabel 3 menunjukkan bahwa asupan makan ibu yang memberikan ASI eksklusif dalam satu hari pada makanan pokok, konsumsi sumber protein, mengonsumsi kuekue dan teh manis $>50$ persen tetapi untuk konsumsi sayur dan buah kurang $<50$ persen.

\section{Karakteristik Informan Penelitian Kualitatif}

Karakteristik informan yang diikut sertakan pada tahap wawancara untuk mengetahui pola makan ibu yang memberikan ASI eksklusif, ditunjukkan pada Tabel 4. Tabel 5 menunjukkan responden wawancara mendalam yang dilakukan dengan menanyakan pola makan dan diperoleh 31 kode 15 kategori dan 4 tema yaitu: jenis makanan yang dikonsumsi, jumlah, frekuensi dan jadwal.

\section{Jenis Makanan}

Jenis makanan yang dikonsumsi merupakan hal yang tidak diperhatikan oleh ibu yang memberikan ASI eksklusif. Setiap ibu mengonsumsi nasi dengan lauk seadanya, tidak variatif untuk jenis makanan dan cara pengolahan makanannya. Sumber makanan dari protein hewani yang dikonsumsi hanya daging ayam, itupun dilihat dari ketersediaan makanan tersebut. Cara pengolahan daging ayam diungkeb lalu digoreng. Untuk telur juga sering dikonsumsi tetapi tercampur dalam nasi kuning sehingga ibu tidak mengonsumsi telur dengan utuh. Untuk protein hewani yang lain seperti daging sapi, ikan, hampir jarang dikonsumsi. Sumber protein nabati yang sering dikonsumsi ibu hanya tahu tempe karena harganya terjangkau dan gampang untuk dimasak seperti digoreng. Hampir semua responden jarang mengonsumsi sayur karena merasa repot mempunyai bayi sehingga memilih masak yang praktis saja tidak usah memotong-motong yang akan di masak. Untuk buah-buahan yang sering di konsumsi pisang yang banyak tersedia di warung. Ibu menyusui mengonsumsi makanan yang praktis untuk disajikan dan sesuai dengan ketersediaan makanan. Hal tersebut dapat dilihat dari hasil wawancara salah satu ibu di bawah ini :

"Yaa.. paling saya maa.. kalo makan, misalnya... kaya makan pagi ya.. beli ajah nasi kuning lebih praktis da sibuk.. nyiapin ini itu.. terus.. yaa ayam yang udah di ungkeb tinggal sreng.. gorenggoreng.. $\mathrm{mm}$ apalagi ya.. paling tahu sama tempe biar gampang terus murah lagi.. kalo sayuran males nyuksak-nyiksik hehe.. keburu si dede uha-ehe hehehe.. kalo buah-buahan ma.. yang ada di warung ajah kaya 
pisang ya yang dibeli itu." (R1A), (R3A), (R4A) dan (R5A),

\section{Jumlah Makanan yang di Konsumsi}

Jumlah makanan dikonsumsi ibu yang memberikan ASI eksklusif sebagian besar porsinya tidak tentu. lbu mengonsumsi makanan tergantung dengan tingkat kelaparan yang ibu rasakan, dan waktu luang untuk makan. Berdasarkan hasil wawancara sebagian besar ibu yang memberikan ASI eksklusif di wilayah kerja UPT Ibrahim Aji, mengonsumsi makanan tertutama karbohidrat seperti nasi dalam jumlah besar dan lauknya sedikit. Hal tersebut tentunya akan memengaruhi asupan makro dan mikro nutrien. Hal tersebut dapat dilihat dari hasil wawancara salah satu ibu di bawah ini :

"Mun sakali emam nu penting ma neng wareg hehehe.. sangu neng sing banyak hehe.. yaa seada ada ajah laukna ma.." (R1A), (R2A), dan (R4A)

\section{Frekuensi makan}

Frekuensi makan ibu yang memberikan ASI eksklusif tidak tentu, tergantung kondisi ibu merasa lapar atau tidak. Ibu merasa lapar pada saat sehabis memberikan ASI pada bayinya. Biasanya setelah memberikan ASI, ibu langsung nyemil kue manis dan minum teh manis. Setelah makan makanan camilan manis, ibu merasa memiliki energi kembali untuk menyusui bayinya. Hal tersebut dapat dilihat dari hasil wawancara salah satu ibu di bawah ini
"Ibu.. kalo sayama berapa kali makan sehari gak tentu.. kadang gimana laparnya hehe.. apalagi kalo udah nenenin.. berasa terkuras energi saya.. hehe.. ya kalo udah nenenin harus makan kue manis, teh manis.. berasa seger lagi gitu.. hehe.. berasa saya bisa kasih nenen lagi.. he..." (R1A), (R2A), dan (R3A)

\section{Jadwal Makan Ibu yang Memberikan ASI Eksklusif}

Jadwal makan utama yang ibu sampaikan yaitu makan pagi/ sarapan pukul 08.00 keatas, makan siang sekitar jam 13.00 keatas, dan untuk makan malam kadang-kadang makan, kadang-kadang tidak makan malam. Namun demikian ibu selalu makan pagi dan siang, namun untuk makan malam tergantung apakah suami pulangnya bawa makanan atau tidak. Jika suami tidak membawa makanan maka ibu akan membeli melalui penjual makanan yang lewat. Pernyataan ibu dapat disimpulkan bahwa ibu tidak teratur dalam jadwal makan. Hal tersebut dapat dilihat dari hasil wawancara salah satu ibu di bawah ini :

"Biasanya ma.. kalo pagi pasti makan cuman agak siang yaa di atas jam delapan.. kalo pas suami dan anakanak sudah pergi.. Siangnya yaa.. gimana si dede kalo si dede bobo siang paling bisa makan abis solat dzuhur sekitar jam satuan ke atas.. teruss.. kalo malem ma.. kadang suami bawa makanan.. atau jajan yang lewat.." (R3A), (R4A)dan (R5A)

Tabel 5

Resume Tema Analisis Kualitatif

\begin{tabular}{llll}
\hline Tema & \multicolumn{1}{c}{ Analisis Content } & \multicolumn{1}{c}{$\begin{array}{c}\text { Hasil Quotasi dari } \\
\text { Transkrip }\end{array}$} & \multicolumn{1}{c}{ Pemaknaan } \\
\hline Jenis & Hampir semua informan & Yaa.. paling saya maa.. & Ibu yang memberikan ASI \\
makanan & menyatakan bahnwa sumber & $\begin{array}{l}\text { kalo makan, misalnya... } \\
\text { eksklusif mengonsumsi }\end{array}$ \\
yang & makanan dari protein hewani yang & kaya makan pagi ya.. beli & nasi dengan lauk \\
dikonsumsi & dikonsumsi hanya daging ayam, & ajah nasi kuning lebih & seadanya, tidak variatif \\
& itupun dilihat dari ketersediaan & praktis da sibuk.. nyiapin & untuk jenis makanan dan \\
& makanan tersebut. Untuk telur tidak & ini itu.. terus.. yaa ayam & cara pengolahan makanan \\
& mengonsumsi telur dengan utuh. & yang udah di ungkeb & yang praktis untuk \\
& Untuk protein hewani yang lain & tinggal sreng.. goreng- & disajikan dan sesuai
\end{tabular}




\begin{tabular}{|c|c|c|c|}
\hline & $\begin{array}{l}\text { seperti daging sapi, ikan, hampir } \\
\text { jarang dikonsumsi. Sumber protein } \\
\text { nabati yang sering dikonsumsi tahu } \\
\text { tempe karena harganya terjangkau } \\
\text { dan gampang untuk dimasak } \\
\text { seperti digoreng. Hampir semua } \\
\text { responden jarang mengonsumsi } \\
\text { sayur karena merasa repot } \\
\text { mempunyai bayi sehingga memilih } \\
\text { masak yang praktis saja tidak usah } \\
\text { memotong-motong yang akan di } \\
\text { masak. Untuk buah-buahan yang } \\
\text { sering di konsumsi pisang yang } \\
\text { banyak tersedia di warung. }\end{array}$ & $\begin{array}{l}\text { goreng.. mm apalagi ya.. } \\
\text { paling tahu sama tempe } \\
\text { biar gampang terus murah } \\
\text { lagi.. kalo sayuran males } \\
\text { nyuksak-nyiksik hehe.. } \\
\text { keburu si dede uha-ehe } \\
\text { hehehe.. kalo buah- } \\
\text { buahan ma.. yang ada di } \\
\text { warung ajah kaya pisang } \\
\text { ya yang dibeli itu. }\end{array}$ & $\begin{array}{l}\text { dengan ketersediaan } \\
\text { makanan }\end{array}$ \\
\hline $\begin{array}{l}\text { Jumlah } \\
\text { makanan } \\
\text { yang } \\
\text { dikonsumsi }\end{array}$ & $\begin{array}{l}\text { Beberapa informan menyatakan } \\
\text { mengonsumsi makanan tergantung } \\
\text { kondisi saat ibu lapar/ tidak dan } \\
\text { waktu luang untuk makan. } \\
\text { Sebagian besar ibu yang } \\
\text { memberikan ASI eksklusif } \\
\text { mengonsumsi karbohidrat seperti } \\
\text { nasi dalam jumlah besar dan } \\
\text { lauknya sedikit. }\end{array}$ & $\begin{array}{l}\text { Mun sakali emam nu } \\
\text { penting ma neng wareg } \\
\text { hehehe.. sangu neng sing } \\
\text { banyak hehe.. yaa seada } \\
\text { ada ajah laukna ma }\end{array}$ & $\begin{array}{l}\text { Jumlah makanan } \\
\text { dikonsumsi ibu yang } \\
\text { memberikan ASI eksklusif } \\
\text { sebagian besar porsinya } \\
\text { tidak tentu. }\end{array}$ \\
\hline $\begin{array}{l}\text { Frekuensi } \\
\text { makan }\end{array}$ & $\begin{array}{l}\text { Beberpa informan menyatakan } \\
\text { frekuensi makan tergantung kondisi } \\
\text { ibu merasa lapar atau tidak saat } \\
\text { sehabis memberikan ASI pada } \\
\text { bayinya. Biasanya setelah } \\
\text { memberikan ASI, ibu langsung } \\
\text { nyemil kue manis dan minum teh } \\
\text { manis. Setelah makan makanan } \\
\text { camilan manis, ibu merasa memiliki } \\
\text { energi kembali untuk menyusui } \\
\text { bayinya. }\end{array}$ & $\begin{array}{l}\text { Bu.. kalo sayama berapa } \\
\text { kali makan sehari gak } \\
\text { tentu.. kadang gimana } \\
\text { laparnya hehe.. apalagi } \\
\text { kalo udah nenenin.. } \\
\text { berasa terkuras energi } \\
\text { saya.. hehe.. ya kalo udah } \\
\text { nenenin harus makan kue } \\
\text { manis, teh manis.. berasa } \\
\text { seger lagi gitu.. hehe.. } \\
\text { berasa saya bisa kasih } \\
\text { nenen lagi.. he.. }\end{array}$ & $\begin{array}{l}\text { Frekuensi makan ibu yang } \\
\text { memberikan ASI eksklusif } \\
\text { tidak tentu. }\end{array}$ \\
\hline $\begin{array}{l}\text { Jadwal } \\
\text { makan }\end{array}$ & $\begin{array}{l}\text { Beberpa informan menyatakan } \\
\text { jadwal makan utama yaitu makan } \\
\text { pagi/ sarapan pukul } 08.00 \text { keatas, } \\
\text { makan siang sekitar jam } 13.00 \\
\text { keatas, dan untuk makan malam } \\
\text { kadang-kadang makan, kadang- } \\
\text { kadang tidak. Namun demikian ibu } \\
\text { selalu makan pagi dan siang, tapi } \\
\text { untuk makan malam tergantung } \\
\text { apakah suami pulangnya bawa } \\
\text { makanan atau tidak. Jika suami } \\
\text { tidak membawa makanan maka ibu } \\
\text { akan membeli melalui penjual } \\
\text { makanan yang lewat. }\end{array}$ & $\begin{array}{l}\text { Biasanya ma.. kalo pagi } \\
\text { pasti makan cuman agak } \\
\text { siang yaa di atas jam } \\
\text { delapan.. kalo pas suami } \\
\text { dan anak-anak sudah } \\
\text { pergi.. Siangnya yaa.. } \\
\text { gimana si dede kalo si } \\
\text { dede bobo siang paling } \\
\text { bisa makan abis solat } \\
\text { dzuhur sekitar jam satuan } \\
\text { ke atas.. teruss.. kalo } \\
\text { malem ma.. kadang suami } \\
\text { bawa makanan.. atau } \\
\text { jajan yang lewat.." }\end{array}$ & $\begin{array}{l}\text { Jadwal makan ibu yang } \\
\text { memberikan ASI eksklusif } \\
\text { tidak teratur. }\end{array}$ \\
\hline
\end{tabular}




\section{BAHASAN}

\section{Asupan Makan Ibu yang Memberikan ASI Eksklusif}

Mayoritas ibu menyusui memiliki asupan energi dan protein yang adekuat ( $\geq 80 \% \mathrm{AKG}$ ). Namun ada 38,63 persen ibu menyusui yang asupan energinya belum adekuat, sedangkan untuk asupan protein ada 40,90 persen mengonsumsi yang belum adekuat. Hasil penelitian tidak sejalan dengan penelitian di Kelurahan Bandarharjo Semarang yang menyatakan sebagian besar ibu menyusui mempunyai asupan energi dan protein yang kurang dari kebutuhan..21 Penelitian di Maori, Pulau Pasifik dan Eropa sama menyatakan ibu menyusui mengonsumsi lebih sedikit energi dan protein. ${ }^{5}$ Asupan energi adekuat ( $\geq 80 \%$ AKG) karena setiap pagi rata-rata ibu mengonsumsi teh manis, memakan nasi dengan porsi yang banyak dibanding dengan lauknya, memakan camilan kue manis setelah ibu menyusui. Untuk asupan protein ibu banyak, mengonsumsi tahu dan tempe karena mudah didapat, harga terjangkau dan cara pengolahannya sangat mudah yaitu digoreng.

Asupan mikronutrien vitamin $A$, vitamin $B 1$, vitamin $B 2$, vitamin $B 6$ dan vitamin $C$ pada ibu yang memberikan ASI eksklusif, semuanya dibawah AKG. Hal ini sejalan dengan penelitian di Maori, Pulau Pasifik, Asian, Eropa menyatakan bahwa vitamin $\mathrm{B} 1$, dan vitamin $\mathrm{C}$ kurang dikonsumsi oleh ibu menyusui di daerah tersebut karena asupan buah, sayuran, kacang, umbi, dan susu dibawah rekomendasi. ${ }^{5}$

Vitamin dan mineral yang kurang dari AKG pada ibu menyusui dikarenakan asupan sayuran, buah-buahan dan susu yang kurang dikonsumsi. Hal ini sejalan dengan penelitian di Hong Kong yang menyatakan bahwa asupan rata-rata sayuran, buah-buahan dan produk susu dari ibu menyusui semua dibawah rekomendasi. Temuan menunjukan bahwa kualitas makanan ibu menyusui harus di perbaiki. ${ }^{22}$

Mikronutrien mineral yaitu kalsium, zat besi dan seng untuk asupan gizi ibu menyusui semuanya kurang dari AKG. Hal ini dikarenakan asupan seperti daging sapi, ayam, telur, ikan dan buah-buahan yang jarang dikonsumsi, ini sejalan dengan penelitian di Korea yang menyatakan asupan seng, bahan makanan hewani, termasuk daging sapi, telur, dan ayam, konsumsi buah dan beras. ${ }^{23}$ Selain itu, faktor pendidikan dapat menyebabkan kurangnya pengetahuan mengenai mineral tersebut karena mayoritas ibu menyusui berpendidikan SMA. Hasil ini selajan dengan penelitian di tiga kota Cina yang menyatakan ibu menyusui memiliki asupan makan yang tidak tepat dan mengakibatkan asupan mineral tertentu tidak mencukupi. ${ }^{24}$ Pada ibu menyusui di Tiga Kota Cina tersebut, asupan kalsium, zat besi dan seng baik pada ibu yang berpendidikan magister. ${ }^{24}$ Pada Penelitian di Ethopia Selatan menyatakan bahwa asupan yang tidak adekuat yaitu vitamin $A$, vitamin $C$, kalsium dan seng sedangkan kalsium asupanya adekuat. ${ }^{25}$

lbu yang memberikan ASI eksklusif, kurang mengonsumsi buah, sayuran, kacang, dan susu. Sebagian besar ibu mengonsumsi vitamin dan mineral di bawah AKG. Wilayah kerja UPT Puskesmas Ibrahim Aji berada di Kota, seharusnya ibu-ibu menyusui di daerah tersebut berpengetahuan lebih baik. Hal ini berbanding terbalik dengan penelitian di Shanghai yang menunjukan bahwa masalah asupan gizi di daerah tersebut terjadi di ibu menyusui yang tinggal di Pedesaan. ${ }^{26}$

Pada penelitian ini ditemukan asupan energi dan makronutrien ibu sudah baik, sedangkan asupan mikronutrien yang masih dibawah AKG. Hal ini sejalan dengan penelitian di Pedesaan Zambia yang menunjukan makronutrien sudah memadai sedangkan asupan mikronutrien tidak memadai. ${ }^{27}$ Pada penelitian di Pinggiran Kota Nepal menunjukan bahwa beras berkontribusi sekitar 60 persen dari asupan energi sedangkan asupan mikronutrien rendah karena keanekaragaman makanan yang dikonsumsi kurang. ${ }^{28}$

\section{Pola Makan Ibu yang Memberikan ASI Eksklusif}

Pola makan pada ibu yang memberikan ASI eksklusif yaitu jenis makanan yang dikonsumsi tidak beragam, jumlah makanan yang dikonsumsi tidak tentu, frekuensi dan jadwal makan yang tidak sesuai dengan anjuran.

Jenis makanan yang dikonsumsi ibu menyusui di wilayah tersebut yaitu nasi yang banyak dengan lauk seadanya. Protein hewani yang dikonsumsi yaitu daging ayam dan telur tetapi tidak sesuai dengan kebutuhan. Sumber 
protein nabati yang sering dikonsumsi yaitu tahu tempe karena harganya terjangkau dan gampang untuk dimasak. Hal ini sejalan dengan penelitian di Kediri yang menyatakan bahwa pangan sumber karbohidrat yang paling sering dikonsumsi adalah nasi sedangkan pangan sumber protein yang paling sering dikonsumsi adalah tahu dan tempe. ${ }^{29}$ Hampir semua ibu yang memberikan ASI eksklusif jarang mengonsumsi sayur karena merasa repot mempunyai bayi sehingga memilih masak yang praktis. Untuk buah-buahan yang sering dikonsumsi pisang yang banyak tersedia di warung. lbu menyusui mengonsumsi makanan yang praktis untuk disajikan dan sesuai dengan ketersediaan makanan. Hal ini sejalan dengan penelitian di Puskesmas Suppa yang menyatakan bahwa buah yang paling sering dikonsumsi yaitu pisang. ${ }^{30}$

Jenis makanan yang dikonsumsi oleh ibu yang memberikan ASI eksklusif, sejalan dengan penelitian yang dilakukan di Pedesaan Malawi yang menyatakan bahwa ibu menyusui tidak mengonsumsi daging, ikan, telur. ${ }^{31} \mathrm{Hal}$ ini berbanding terbalik dengan penelitian di Woreda Ethiopia yang menyatakan bahwa ibu menyusui sebagian besar mengonsumsi bijibijian, gandum dan umbi-umbian. ${ }^{32}$ Penelitian di Puskesmas Kedungmundu Kota Semarang menunjukan sebagian besar keberagaman makanan ibu menyusui terdiri dari 4-5 jenis kelompok pangan. Kelompok pangan yang sering dikonsumsi adalah nasi, jagung, umbiumbian, kacang-kacangan, makanan bersumber nabati, sayuran dan buah-buahan | lainnya. ${ }^{33}$

Jenis makanan yang tidak beragam karena pengetahuan yang rendah yang disebabkan oleh pendidikan yang kurang dan penghasilan yang rendah karena hampir semua ibu menyusui tidak bekerja sehingga untuk daya beli mereka kurang dan untuk mendapatkan informasi dengan komunikasi dari sesama rekan kerja atau sedikit peluang untuk berbagi informasi dan pengalaman dengan ibu lain. Hal ini sejalan dengan penelitian di Pekalongan yang menyatakan bahwa pendidikan dan penghasilan dapat mempengaruhi perilaku seseorang termasuk perilaku dalam pola hidup. $^{34}$ Penelitian di kota Aksum, Tigray, Ethiopia Utara menyatakan bahwa keragaman diet diantara ibu menyusui rendah dikarenakan pendapatan bulanan yang kurang. ${ }^{35}$
Banyaknya jumlah makanan yang dikonsumsi ibu menyusui sebagian besar porsinya tidak tentu. lbu mengonsumsi makanan jika merasa lapar, dan ada waktu luang untuk makan. Komposisi makanan yang dikonsumsi yaitu nasi dalam jumlah besar dan lauknya sedikit. Hal ini sejalan dengan penelitian etnografi pada suku Jawa yang menunjukan bahwa ibu menyusui meningkatkan porsi pada nasi karena diyakini akan menambah banyaknya $\mathrm{ASI}$, selain alasan bahwa memperbanyak karbohidrat karena mudah lapar sedangkan sayuran dan lauk dikonsumsi hanya dengan jumlah secukupnya. ${ }^{36}$ Berbanding terbalik dengan penelitian di Kota Kediri yang menyatakan bahwa ibu menyusui mengonsumsi karbohidrat 3-4 porsi/hari dan protein 2-3 porsi/hari. ${ }^{29}$

Frekuensi makan ibu yang memberikan ASI eksklusif tidak tentu, tergantung kondisi ibu merasa lapar atau tidak. Ibu merasa lapar sehabis memberikan ASI pada bayinya. Hal ini sejalan dengan penelitian di Lowokmaru Malang yang menyatakan bahwa frekuensi makan ibu menyusui saat ibu merasa lapar. ${ }^{37} \mathrm{lbu}$ yang memberikan ASI eksklusif biasanya setelah memberikan ASI, ibu langsung nyemil kue manis dan minum teh manis. Hal ini tidak sejalan dengan frekuensi makan ibu menyusui di Puskesmas Suppa termasuk dalam kategori cukup dalam frekuensi makan sayur dan buah. ${ }^{30}$

Jadwal makan yang tidak sesuai dengan anjuran pada ibu menyusui, dikarenakan ibu sarapan pada pukul 08.00 keatas, makan siang sekitar jam 13.00 ke_atas, dan untuk makan malam kadang-kadang makan atau kadangkadang tidak makan malam. Hal ini tidak sejalan dengan penelitian di Kecamatan Lowokwaru Kota Malang, yang menunjukan bahwa ibu menyusui sarapan pagi antara jam 06.00-09.00 setiap hari, makan dengan jarak antara $\leq 6$ jam, setiap hari melakukan makan siang dan makan malam serta mengonsumsi makanan yang bisa melancarkan produksi ASI seperti sayur rebus, buah-buahan dan kacang-kacangan. ${ }^{37}$

Pola makan ibu yang memberikan ASI eksklusif yang tidak tepat, berpotensi menyebabkan kuantitas dan kualitas ASI yang tidak baik sehingga dapat berakibat pada pertumbuhan dan perkembangan bayi. ${ }^{22} \mathrm{Hal}$ ini disebabkan karena rendahnya pengetahuan ibu mengenai asupan yang seharusnya. 
Ketersediaan bahan pangan dalam rumah tangga berdampak pada variasi dan jenis makanan yang diberikan baik secara kualitas maupun kuantitas.

Disarankan perlu adanya penyuluhan atau konseling gizi mengenai dan pola makan ibu yang memberikan ASI eksklusi serta monitoring dan evaluasi yang berkelanjutan terhadap program kerja yang difokuskan pada masalah asupan makan ibu menyusui. Ibu maupun keluarga dapat berpartisipasi aktif dalam pemenuhan nutrisi ibu menyusui sehingga ASInya banyak dan berkualitas yang dapat berpengaruh terhadap pertumbuhan bayi. Perlu penelitian lebih lanjut untuk mengetahui kualitas ASI dari pola makan ibu menyusui yang dihubungkan dengan perkembangan bayi.

Keterbatasan penelitian ini adalah metode food recall 24 hours ini berdasarkan daya ingat ibu, sehingga memungkinkan terjadinya bias recall berupa pelaporan asupan yang dikonsumsi lebih banyak atau lebih sedikit. Keterbatasan pada triangulasi metode yaitu peneliti tidak dapat melihat langsung/ observasi pola makan ibu menyusui yang memberikan ASI eksklusif dalam keseharinya.

\section{SIMPULAN DAN SARAN}

\section{Simpulan}

Mayoritas ibu yang memberikan ASI eksklusif di wilayah kerja UPT Puskesmas Ibrahim Aji memiliki asupan energi dan protein yang adekuat, sedangkan pada asupan vitamin $A$, vitamin $B 1$, vitamin $B 2$, vitamin $B 6$, vitamin $C$, kalsium, seng dan zat besi masih di bawah AKG. Pola makan ibu yang memberikan ASI eksklusif belum sesuai dengan anjuran gizi seimbang.

\section{Saran}

Perlu dilakukan konseling gizi tentang pentingnya asupan makan ibu yang memberikan ASI eksklusif dan pola makan secara terus-menerus baik melalui kader, bidan, petugas gizi dan tokoh masyarakat. Puskesmas perlu melakukan monitoring terhadap asupan makan dan pola makan yang diberikan terhadap ibu yang memberikan ASI eksklusif.

\section{UCAPAN TERIMA KASIH}

Terima kasih kepada UPT Puskesmas Ibrahim Aji Kota Bandung yang telah memberi izin serta memfasilitasi penelitian ini.

\section{RUJUKAN}

1. Dewi R, Santy FN. Pengalaman ibu bekerja dalam memberikan asi eksklusif. Jurnal Kesehatan Panca Bhakti Lampung. 2018; VI(2): 78-87.

2. Kemenkes RI. Profil kesehatan Indonesia. 2016.

3. Kemenkes RI. Dinas kesehatan Provinsi Jawa Barat. 2016.

4. Kemenkes Rl. Profil kesehatan Kota Bandung. 2016.

5. Butts CA, Hedderley DI, Herath TD, Paturi G, Glyn-Jones S, Wiens F, Stahl B, Gopal P. Human milk composition and dietary intakes of breastfeeding women of different ethnicity from the ManawatuWanganui Region of New Zealand. Nutrients. 2018; 10(9): 1231.

6. Kemenkes Rl. Pusat Data dan Informasi. 2014.

7. Setyarini $A$, Mexitalia M, Margawati $A$. Pengaruh pemberian ASI eksklusif dan non eksklusif terhadap mental anak usia 34 tahun. Jurnal Gizi Indonesia. 2015; 4: 16-21.

8. Kumar $T$, Kumar $S$, Sunita, Kumar $M$, Jhillmill, Anju, Sharan A. Study on effects of exclusive breastfeeding on immunity of infants. Indian Journal of Public Health Research \& Development. 2016; 7(2): 300303.

9. Damayanti RA, Muniroh L, Farapti. Perbedaan tingkat kecukupan zat gizi dan riwayat pemberian ASI eksklusif pada balita stunting dan non stunting. Media Gizi Indonesia. 2016; 11(1): 61-69.

10. Banerjee N, Chakraborty A, Lahiri A, Biswas K. Exclusive breast feeding reduces diarrhoeal episodes among children: results from a cross-sectional study among the mothers of under-five children in Kolkata. International Journal Community Medicine Public Health. 2019; 6(2): 733-737. 
11. Herawati DMD. Kebutuhan Nutrisi Pada Siklus Hidup Manusia. Cet Ke-I. Bandung: 2016.

12. Sugihantono A. Pedoman Gizi Seimbang. Jakarta: Bakti Husada; 2014.

13. Radharisnawati, Ni Kadek. Kundre, Rina. Pondaag L. Hubungan pemenuhan kebutuhan gizi dengan kelancaran air susu ibu (ASI) pada ibu menyusui di Puskesmas Bahu Kota Manado. e-journal Keperawatan. 2017; 5(1).

14. Su MY, Jia HX, Chen WL, Qi XY, Liu CP, Liu ZM. Macronutrient and micronutrient composition of breast milk from women of different ages and dietary habits in Shanghai area. Elsevier. 2018; 85: 27-34.

15. Tian HM, Wu YX, Lin YQ, Chen XY, Yu M, Lu T, Xie L. Dietary patterns affect maternal macronutrient intake levels and the fatty acid profile of breast milk in lactating Chinese mothers. Nutrition. 2019; 58: 83-88.

16. Prentice $P$, Ong KK, Schoemaker MH, van Tol EA, Vervoort J, Hughes IA, Acerini CL, Dunger DB. Breast milk nutrient content and infancy growth. Pubmed. 2016; 105(6): 641-7.

17. Wibowo M. Dukungan informasi bagi ibu menyusui dalam memberikan asi eksklusif di kecamatan gondokusuman, yogyakarta. Jurnal Kesehatan Masyarakat. 2016.

18. Kusparlina EP. Hubungan antara asupan nutrisi dengan kelancaran produksi ASI pada ibu yang menyusui bayi 0-6 bulan. Jurnal Delima Harapan. 2020; 7(2): 113117.

19. Imasrani IY, Utami NW, Susmini. Kaitan pola makan seimbang dengan produksi ASI ibu menyusui. Jurnal care. 2016; 4(3): 1-8.

20. Rachmat M. Buku Ajar Biostatistika Aplikasi Pada Penelitian Kesehatan. EGC; 2013.

21. Wardana RK, Widyastuti N PA. Hubungan asupan zat gizi makro dan status gizi ibu menyusui dengan kandungan zat gizi makro pada ASI di Kelurahan Bandarharjo Semarang. Jurnal Nutriton Collage. 2018.

22. Wong. Vincy W. Nutritional characteristics of breast milk in Hong Kong lactating women. Hong Kong Polytechnic University. 2018.
23. Choi YK, Kim JM, Lee JE, Cho MS, Kang BS, Choi H, Kim Y. Association of maternal diet with zinc, copper, and iron concentrations in transitional human milk produced by Korean Mothers. Pubmed. 2016; 5(1): 15-25.

24. Zhao A, Xue Y, Zhang Y, Li W, Yu K, Wang $P$. Nutrition concerns of insufficient and excessive intake of dietary minerals in lactating women: a Cross-sectional survey in three cities of China. Plos One. 2016.

25. Girma M, Seid H, Tilahun B, Stoecker BJ. Inadequate zinc and calcium but adequate iron intakes in lactating women from southern Ethiopia. Faseb Journal. 2017; 31(1)

26. Hu R, Fei J, Zhai Y, Feng Y, Warren J, Jin Y, Papi B, Stahl B, Wang Z, Li J. The dietary intake of two groups of lactating women in shanghai during the puerperium. Pubmed. 2019; 28(1): 106-115.

27. Kaliwile $C$, Michelo $C$, Titcomb TJ, Moursi M, Donahue AM, Reinberg C, Bwembya P, Alders R, Tanumihardjo SA. Dietary Intake Patterns among Lactating and NonLactating Women of Reproductive Age in Rural Zambia. Nutrients. 2019; 11(2): 112.

28. Henjum S, Torheim LE, Thorne-Lyman AL, Chandyo R, Fawzi WW, Shrestha PS, Strand TA. Low dietary diversity and micronutrient adequacy among lactating women in a peri-urban area of Nepal. Public Health Nutrition. 2015; 18(17): 3201-10.

29. Triatmaja NT, I Rizky 0 , Hidayat $A$. Determinan masalah gizi kurang (status kurang energi kronis) pada ibu menyusui berdasarkan aspek individu dan rumah tangga di Kota Kediri. Jurnal Wiyata. 2018; 5: 69-76.

30. Hardiyanti N, Majid M, Umar F. Hubungan pola makan ibu menyusui dengan status gizi bayi usia 0-6 bulan di wilayah kerja Puskesmas Suppa. Jurnal IImiah Manusia dan Kesehatan. 2018; 1(3): 242-254.

31. Kang Y, Hurley KM, Ruel-Bergeron J, Monclus AB, Oemcke R, Wu LSF, Mitra M, Phuka J, Klemm R, West KP, Christian P. Household food insecurity is associated with low dietary diversity among pregnant and lactating women in rural Malawi. Public Health Nutrition. 2019; 22(4): 697705. 
32. Julla BW, Haile A, Ayana G, Eshetu S, Kuche D, Asefa T. Chronic energy deficiency and associated factors among lactating Mothers (15-49 years old) in Offa Woreda, Wolayita Zone, SNNPRs, Ethiopia. World Scientific Research. 2018; 5(1): 13-23.

33. Fauzia S. Rahayuning D. Widajanti L. Hubungan keberagaman jenis makanan dan kecukupan gizi dengan indeks massa tubuh (IMT) pada ibu menyusui di wilayah kerja Puskesmas Kedungmundu Kota Semarang Tahun 2016. Jurnal Kesehatan Masyarakat. 2016; 4(3): 233-242.

34. Kristiyanti R, Khuzaiyah S. Karakteristik ibu nifas yang berpantangan makanan. University Research Colloqium. 2018; 355359.

35. Weldehaweria NB, Misgina KH, Weldu MG, Gebregiorgis YS, Gebrezgi BH,
Zewdie SW, Ngusse HA. Gebrewa HG, Alemu W. Dietary diversity and related factors among lactating women visiting public health facilities in Aksum town, Tigray, Northern Ethiopia. BMC Nutrition. 2016; 1-9.

36. Hidayati R. Persepsi ibu postpartum yang menyusui dalam memenuhi kebutuhan nutrisi: suatu studi Ethnography pada suku Jawa. Jurnal Ners. 2016; 11: 195-200.

37. Imasrani IY, Utami NW, Susmini. Hubungan pola makan seimbang dengan produksi ASI ibu menyusui di Tlogo Indah Kecamatan Lowokwaru Malang. Nurs News. 2017; 2: 568-577. 